\author{
J. Janssen \\ G. Gijselings \\ E. Paulissen \\ P. M. Vermeersch
}

\title{
Middle Palaeolithic Chert Exploitation Pits near Qena (Upper
}

\section{Egypt)}

In: Paléorient. 1986, Vol. 12 №1. pp. 61-65.

\begin{abstract}
The existence of Middle Palaeolithic exploitation pits for chert cobbles is noted on the surface of a Nile terrace at $7 \mathrm{~m}$ above the floodplain. A sample of lithic artifacts shows that Levallois technology is utilized exclusively.

\section{Résumé}

L'existence de puits d'extraction de galets de silex du Paléolithique Moyen est observée à la surface d'une terrasse nilotique se situant à $7 \mathrm{~m}$ au-dessus de la plaine alluviale. Un échantillon d'artefacts prouve que les galets de silex extraits des puits ont servi exclusivement au débitage Levallois.
\end{abstract}

Citer ce document / Cite this document :

Janssen J., Gijselings G., Paulissen E., Vermeersch P. M. Middle Palaeolithic Chert Exploitation Pits near Qena (Upper Egypt). In: Paléorient. 1986, Vol. 12 N¹. pp. 61-65.

doi : 10.3406/paleo.1986.4399

http://www.persee.fr/web/revues/home/prescript/article/paleo_0153-9345_1986_num_12_1_4399 


\title{
MIDDLE PALAEOLITHIC \\ CHERT EXPLOITATION PITS NEAR QENA (UPPER EGYPT)
}

\author{
P.M. VERMEERSCH, E. PAULISSEN, G. GIJSELINGS and J. JANSSEN
}

ABSTRACT. - The existence of Middle Palaeolithic exploitation pits for chert cobbles is noted on the surface of a Nile terrace at $7 \mathrm{~m}$ above the floodplain. A sample of lithic artifacts shows that Levallois technology is utilized exclusively.

RÉSUMÉ. - L'existence de puits d'extraction de galets de silex du Paléolithique Moyen est observée à la surface d'une terrasse nilotique se situant à $7 \mathrm{~m}$ au-dessus de la plaine alluviale. Un échantillon d'artefacts prouve que les galets de silex extraits des puits ont servi exclusivement au débitage Levallois.

materials. Beside the quarry, in the back airt or a recent hole, a huge amount of clearly Middle Palaeolithic artifacts were found.

The top of the Nile cobble deposits is situated at about $7 \mathrm{~m}$ above the Nile floodplain. These former

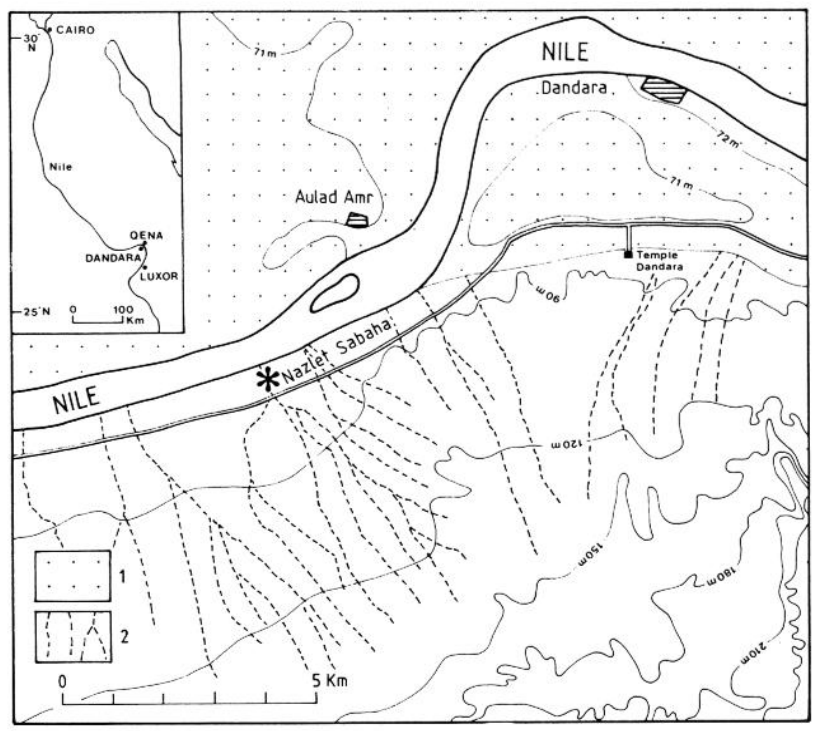

FIG. 1. - Site location; 1 : irrigated fields; 2 : wadi beds and lower desert.

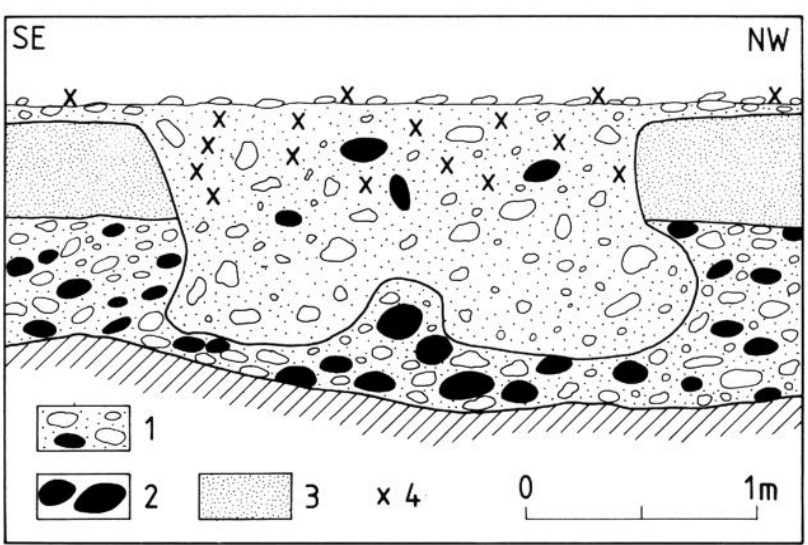

FIG. 2. - Profile of quarry wall with man-made pit; 1 : terrace deposits; 2 : chert cobbles; 3 : aeolian sands; 4 : artifacts.

channel lag deposits are 2 to $3 \mathrm{~m}$ thick. They rest on very coarse Nile sands and were originally covered with medium Nile sands, still sporadically preserved in the area. The $7 \mathrm{~m}$ terrace cobble deposits contain metamorphous, eruptive, quartz and chert cobbles with a diametre of up to $20 \mathrm{~cm}$. The chert cobbles are round or ellipsoidal. The terrace deposits are actually overlain by an aeolian sand sheet of variable thickness $( \pm 30 \mathrm{~cm})$ with on top a desert pavement. In these deposits man-made pits could be observed, such as the one on figure 2 , wich has steep edges and an irregular bottom. It has a total depth of about $1 \mathrm{~m}$. The filling of the pit is much more sandy, more heterogeneous and contains less cobbles than the original Nile deposit. Its composition is similar to that of the Nile terrace except for an underrepresentation of chert gravels and a chaotic presence of cores and flakes, some of which are clearly of Levallois technology.

Such an observation suggests that the chert cobbles have been selected from the terrace deposits 

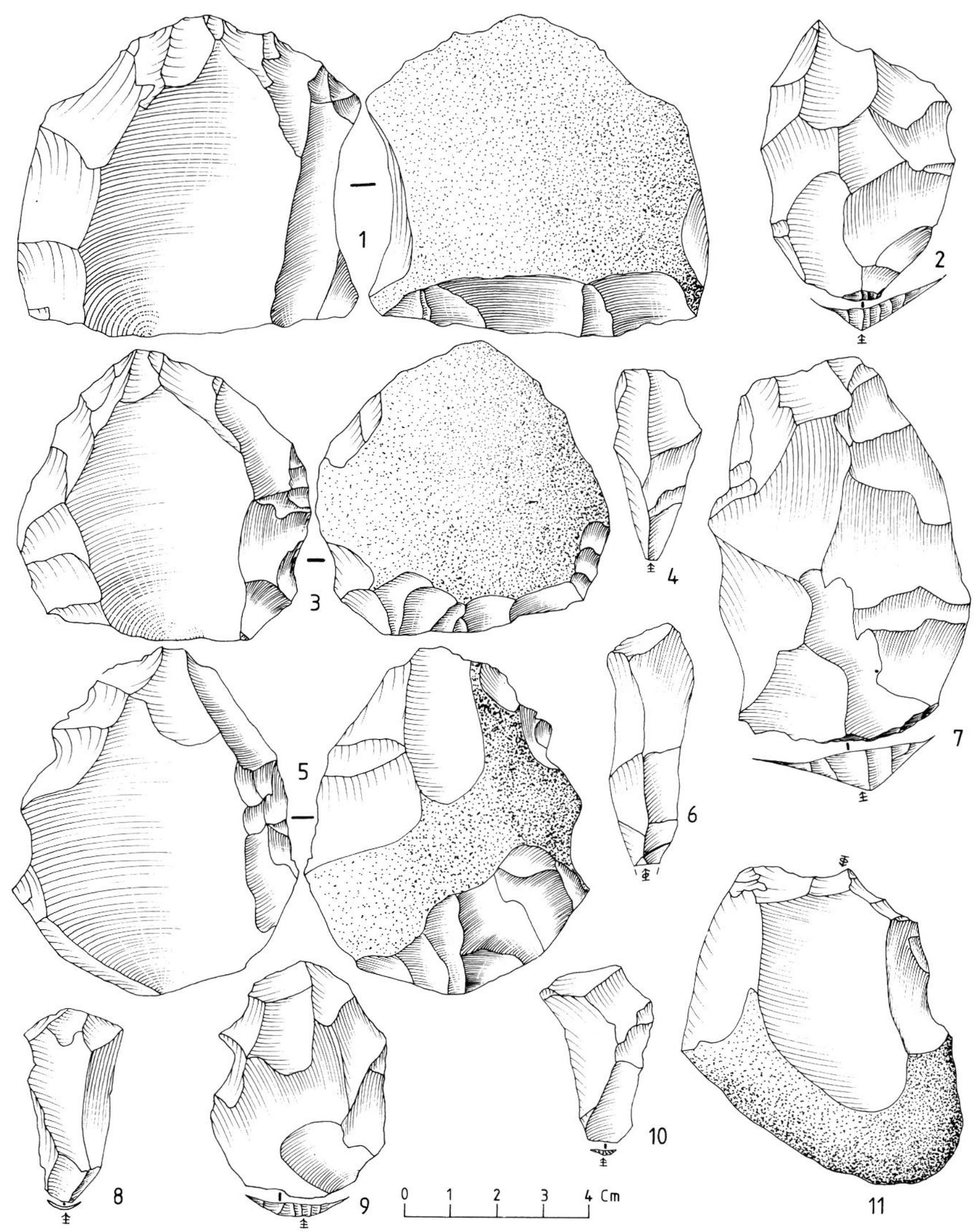

6
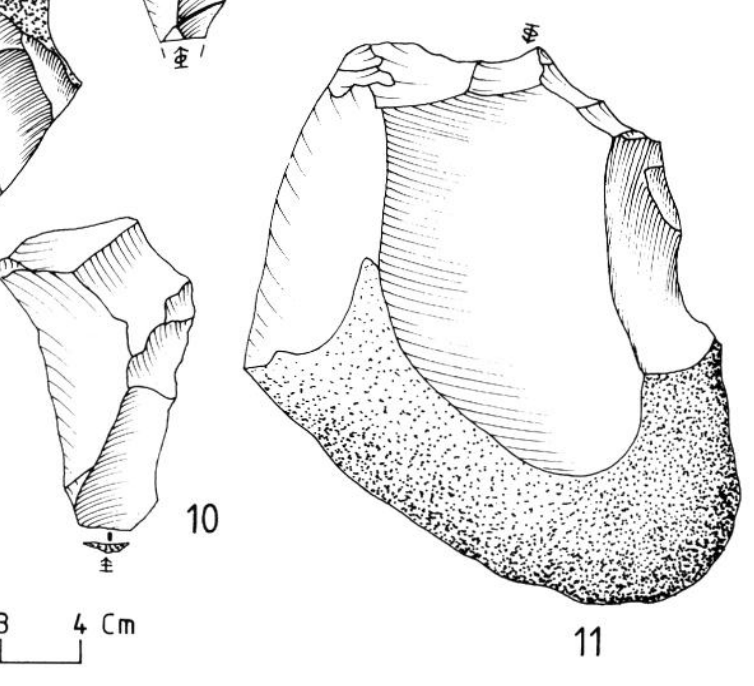

FIG. 3. - 1,3,5 : Levallois cores; 2,7,9 : Levallois flakes; 4,6,8,10 : preparation bladelets; 11 : denticulated scraper. 

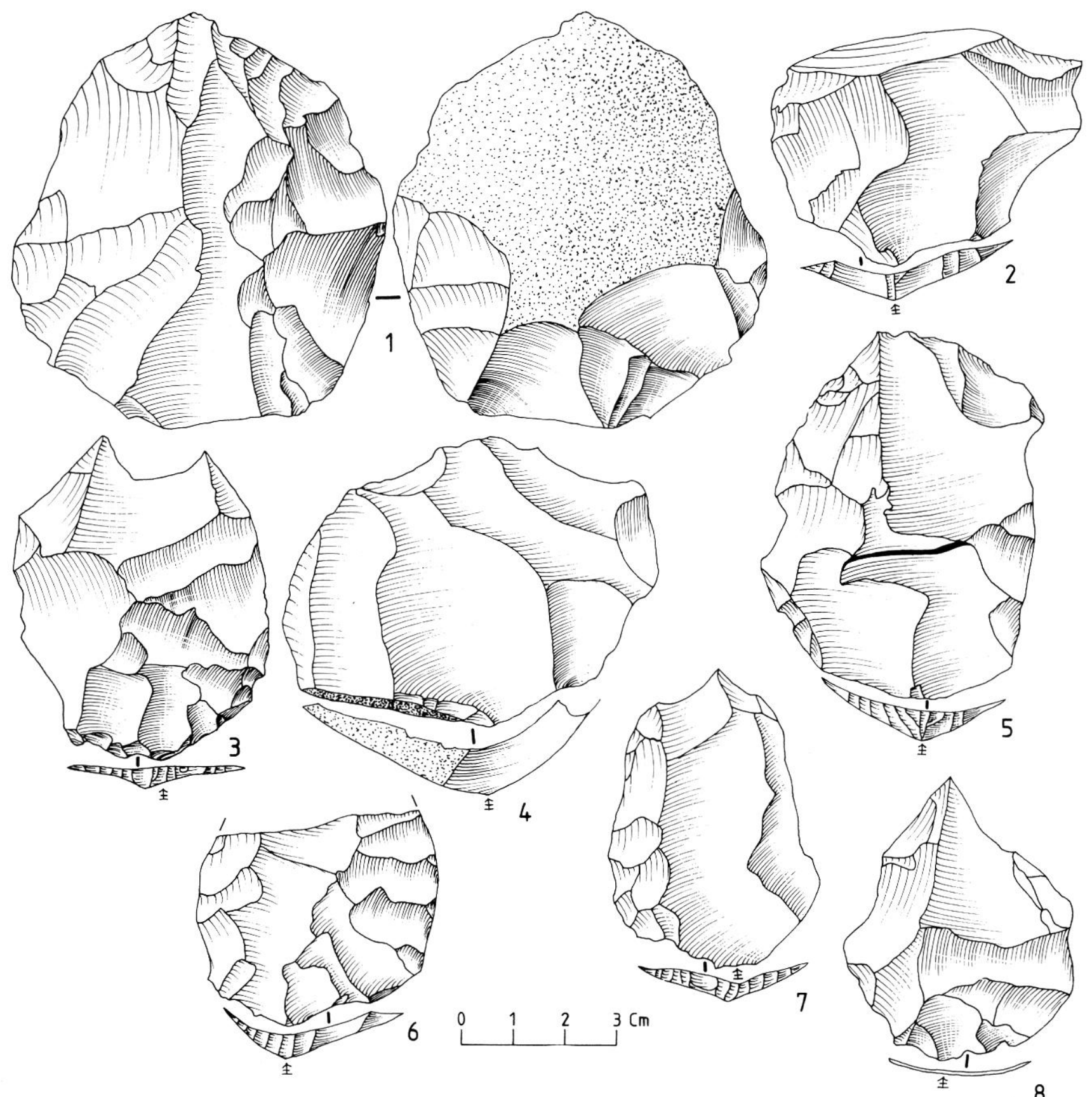

FIG. 4. - 1 : Levallois core; $2-8$ : Levallois flakes.

by digging pits in order to utilize these as blanks for cores. The chert was sorted out and the other materials were dumped in the exploited pits. Chert knapping took place on the spot. It seems that there is contemporaneity between pit digging, debitage activity and subsequent filling. This resulted in the occurrence of debitage materials in the pit filling.

We clearly have here evidence for the exploitation by Middle Palaeolithic man of the chert he needed for the manufacture of artifacts. This exploitation extended by merely digging small pits.
Nearby the quarry, the back dirt of a recent disturbance in the terrace surface yielded thousands of extremely fresh cores, flakes and also very small chips. From an inspection of the walls of this hole it became clear that the archaeological material presents a position similar to that of the artifacts from the small pits in the quarry. No excavation was initiated to check this working hypothesis. We hope to do this in one of our coming campaigns.

The lithic artifacts recovered from this disturbance are representative of an exclusively Levallois 
technology. Ellipsoidal chert cobbles were chosen for preparing the cores.

Core preparation (fig. $3: 1,3,5 ; 4: 1$ ) is mainly restricted to centripetal flaking of the upper core surface, whereas on the obverse surface the preparation consisted of removing only a few flakes. Sometimes the preparation is somewhat of Halfan style (1) with removal of different bladelet-like preparations on the distal side. The bulb imprint is large and deep, such as is normally the case with Levallois cores. Some of the cores attest the successive removal of different Levallois flakes from a single core. This system we know from other Levallois assemblages, that were excavated by us such as Nazlet Khater-2. The removal negatives of the Levallois flakes exhibit an oval to cordiform shape; sometimes short blades (fig. $3: 4,6,8,10$ ) have been produced. Occasionally quartz cobbles have also been utilized for producing levallois flakes. Different quartz flakes could be refitted on the spot, enhancing the research potentialities of the site.

After removal of the last Levallois flake, cores became rather thin $(\bar{X}: 24 \mathrm{~mm} ; \mathrm{N}: 16)$, which could be an indication of their complete exhaustion. Nubian type cores(2) are lacking in our small sample of sixteen cores.

The Levallois flakes are of good quality. They are thin $(\bar{X}: 4.9 \mathrm{~mm} ; \mathrm{N}: 32)$. Their contour is oval, rectangular or cordiform (fig. $3: 2,7,9 ; 4: 2-8$ ). The butt is always carefully facetted and often "en forme de chapeau de gendarme". All sorts of preparation flakes are well represented. Only one tool has been recovered : a denticulated side-scraper (fig. $3: 11$ ).

As the Middle Palaeolithic sites from the Egyptian Nile valley, excavated during earlier campaigns of the B.M.E.P.P., are still in study ( 3 and 4 ), it is presently premature to undertake a detailed comparaison with the Nazlet Sabaha Garb materials. For the time being we may state that the sites of Nazlet Khater-2 and Beit Allam (5) are also characterized by a Levallois technology in which the Nubian technique is poorly represented.

A detailed survey on the surface of the terrace remnant and along all quarry faces revealed the presence of other exploitation sites in the surroundings. Some of them seem to have been oriented towards blade production of Late Palaeolithic technology. As far as we can understand now, the chert cobbles of the Nile terrace have been extensively mined by prehistoric man, probably over a long period of time, starting at least with the Middle Palaeolithic and continuing during the late Palaeolithic. The exploitation techniques were simple but well adapted to the natural chert occurrences.

(1) MARKS, 1968.

(2) GUICHARD and GUICHARD, 1965.

(3) By P. VAN PEER, Katholieke Universiteit Leuven, Belgium.

(4) PAULISSEN, VERMEERSCH, in press.

(5) VERMEERSCH et al., 1978.
At the Lion Cavern in Swaziland, Middle Stone Age people were mining for hematite by perhaps 110,000 years ago (6) by cutting into the side of a hematite cliff face. At Lovas, Hungary, hematite extraction from a pit down to $2.5 \mathrm{~m}$ has been attributed to the early Upper Palaeolithic (7).

In Nubia extraction of Nubian sandstone has been reported for the Middle Palaeolithic site Arkin $5(8)$. Here small pits have been dug down to $35 \mathrm{~cm}$ deep. Recently we reported from Nazlet Khater-4 near Tahta, Upper Egypt, the existence of a chert mining site with a system of trenching and vertical shafts (9) from the early Late Palaeolithic, C-14 dated at 33,000 years ago.

In other parts of the world, like in Europe, systematic exploitation of chert and flint seems to be restricted to the end of the Last Glacial and the Holocene.

With the evidence of Nazlet Sabaha Garb it becomes once more clear that chert extraction in an organized way is much older than generally thought. It indicates that Middle Palaeolithic man was well aware of the geological and petrographical potentialities of cobble beds and was able to organize a systematic exploitation (10).

\section{P.M. VERMEERSCH, E. PAULISSEN, G. GIJSELINGS and J. JANSSEN Katholieke Universiteit te Leuven (Belgique)}

\section{BIBLIOGRAPHY}

\author{
CHMIELEWSKI W. \\ 1965 Archaeological Research on Pleistocene and Lower \\ Holocene Sites in Northern Sudan: Preliminary \\ Results. In WENDORF F. (ed.) Contributions to the \\ Prehistory of Nubia : 147-164. Dallas : S.M.U. Press. \\ GUICHARD J. and GUICHARD G. \\ 1965 The Early and Middle Palaeolithic of Nubia : \\ A Preliminary Report. In WENDORF F. (ed.) \\ Contributions to the Prehistory of Nubia: 57-116. \\ Dallas : S.M.U. Press. \\ MARKS A.E. \\ 1968 The Halfan Industry. In WENDORF F. (ed.) The \\ Prehistory of Nubia : 392-460. Dallas : S.M.U. Press. \\ (6) VOLMAN, 1984. \\ (7) MESZAROS and VERTES, 1955. \\ (8) CHMIELEWSKI, 1965 \\ (9) VERMEERSCH et al., 1984. \\ (10) Our thanks are due to the Belgian 'Fonds voor Kollektief \\ Fundamenteel Onderzoek' and the 'Onderzoeksfonds, Katholieke \\ Universiteit te Leuven' for funding; the Egyptian Antiquities \\ Department for support and D. Huyge for improving our English \\ text.
}


MESZAROS G. and VERTES L.

1955 A paint mine from the early Upper Palaeolithic age near Lovas (Hungary, County Veszprém). Acta Archaeologica Academiae Scientiarum Hungaricae $5: 1-34$

PAULISSEN E. and VERMEERSCH P.M.

in press Earth, Man and Climate in the Egyptian Nile Valley during the Pleistocene. In CLOSE A. (ed.) Adaptation towards Aridity. Dallas : S.M.U. Press.

VERMEERSCH P.M., PAULISSEN E., GIJSELINGS G., OTTE

M., THOMA A., VAN PEER P. and LAUWERS R.

$1984 \quad 33,000$-yr old chert mining site and related Homo in the Egyptian Nile Valley. Nature, $309: 342-344$.
VERMEERSCH P.M., PAULISSEN E., OTTE M., GIJSELINGS G., and DRAPPIER D.

1978 Middle Palaeolithic in the Egyptian Nile Valley. Paléorient, $4: 245-252$

VOLMAN T.P.

1984 Early Prehistory of Southern Africa. In KLEIN R.G. (ed.) Southern African Prehistory and Paleoenvironments : 169-220. Rotterdam : Balkema. 